\title{
The Expansion of Nickel Mining, Environmental Damage and Determinants' of the Bajo Community Marginalization in Pomalaa Regency, Southeast Sulawesi ${ }^{1}$
}

\author{
Irawati ${ }^{2}$
}

\begin{abstract}
Abstraksi
Penelitian ini dilatarbelakangi oleh tata kelola yang kurang tepat dalam pengelolaan sumber daya alam yang seharusnya melibatkan masyarakat dalam menjaga kelestarian lingkungan agar dapat terus sejahtera. Namun, ekspansi pertambangan nikel di Pomalaa, Kabupaten Kolaka telah mengakibatkan jurang yang besar antara si kaya dan si miskin. Hal tersebut juga mempengaruhi kelangsungan hidup masyarakat Bajo. Penelitian ini bertujuan untuk mengungkap determinan atau alasan mengapa masyarakat Bajo terpinggirkan, terutama akibat ekspansi pertambangan di Pomalaa, Kabupaten Kolaka. Metode penelitian dilakukan dengan paradigma post-positivism dengan menerapkan pendekatan grounded theory untuk analisisnya. Studi tersebut mengidentifikasi tiga faktor penentu utama marjinalisasi masyarakat Bajo. Pertama, air yang tercemar akibat pencemaran pantai. Kedua, tidak tersedia dukungan mata pencaharian alternatif karena terbatasnya akses untuk mendapatkan manfaat ekonomi dari perluasan pertambangan. Ketiga, lemahnya daya tawar masyarakat Bajo dalam menghadapi politik perusakan lingkungan akibat terbatasnya akses masuk ke dalam struktur pembuat kebijakan yang dilestarikan oleh norma budaya lokal.
\end{abstract}

Kata kunci: determinan sosial ekonomi, dampak ekologi tata kelola SDA, marginalisasi, ekspansi pertambangan, komunitas Bajo

Abstract

Background of this research is the mismanagement of natural resources that ignores supposedly the involvement of the locals to preserve environment for their continuously prosperity. Yet, the expansion of nickel mining in Pomala, Kolaka Regency has resulted in a big gap between the richer and the poors. It has also been affected life survival of the Bajo community. The research aims at revealing determinants or the reasons why the Bajo community has been marginalized, especially due to mining expansion in Pomala, Kolaka Regency. The research method is conducted with post-positivism paradigm by applying grounded theory approach for analysis. The study identifies three major determinants of the Bajo community's marginalization. First, contaminated water due to coastal pollution. Second, unavailable alternative livelihood supports due to limited access for economic benefits from the mining expansion. Third, lacking bargaining ability of the Bajo community in dealing with the politics of the environmental destruction due to limited access for entering the structure of policymakers preserved by the local cultural norms.

Keywords: socio economic determinants, ecological impacts of natural resources mismanagement, marginalization, mining expansion, the Bajo community

\section{A. Background}

The expansion of nickel mining companies in Pomala sub District, Kolaka Regency, Southeast Sulawesi Province, is a proof to say that the neoliberal capitalism is an economic system that only benefitted a small number of people, and thus has been resulted in more complex social classes division in society. This study is thus motivated to examine such claim. Previous research conducted by the Departement of Social and Environmental Study, Haluleo University in 2009 for instance, shows the fact of socio-economic precarity of the Pomalaa people due to extensive minings by the modus of land or forests clearance that

\footnotetext{
${ }^{1}$ To cite this article: Irawati. 2020. “The Expansion of Nickel Mining, Environmental Damage and Determinants' of the Bajo Community Marginalization in Pomalaa Regency, Southeast Sulawesi”. Jurnal Pemikiran Sosiologi Vol 7 (2): 139-151

${ }^{2}$ Sociology Department, Universitas Negeri Sebelas November, Indonesia. Email: irawati880@ymail.com
} 
has been resulted in increased sedimentation along the coastal areas. According to the study, the sedimentation of mining mud entering through the rivers in the Pomala sea water accounted for 1,330,281 m3 / year with a silting rate of $0.507 \mathrm{~m} /$ year. It is predicted that in 2019 , the depth contours of 1-3 meters will change to 923.4 hectares of land. So that the area of Pomala water at that time was 197.1 hectares.

Given the fact that coastal environment of Hakatutobu village has been damaged by the mining activities, most local people in the area have changed their life survival strategy. They are now breeding fish by building fish captivations in the middle of the sea so that the fish population in Hakatutobu Village remains sustainable. However, the main reason for the local people to change their life survival now is also under further threat. This is because the coastal area of Hakatutobu where they occupy as a site for cultivating seaweed and sea cucumbers has also been deteriorated by the traffics of shipload containers of mud from the land clearance. The Pomalaa sub District, Hakatutobu village is the area that is most severely affected by the mining activities. So that with the destruction of the aquatic environment as previously described, the Bajo community experiences a highly constant marginalization.

\section{B. Research Method and Theoretical Concept}

This study is conducted by a post-positivism paradigm combined with a grounded research approach (Strauss and Corbin, 2003). Data for the study are collected from interviews, observation and other related or supporting documents (Lincoln and Guba, 1985: 20). Data analysis applied for this study is a qualitative method that seeks to find a central meaning that operates in the research findings. Presentation of the data is written by narrative analysis accompanied by the discussion of various perspectives based on post-postivism paradigm.

Based on the above background, this study seeks to post general research questions as follows; "Which determinants of the environmental destruction in the areas that contribute to the Bajo community's marginalization?" and "how the Bajo community seek to struggle with their life survival affected by the deterioration of the nearby expansion mining activities in Pomalaa areas especially in the villages of Hakatutobu (that mostly severely marginalized) and its neighbor village of Tambea where the Bajo community also live?" Those two general research questions will provide a better understanding for the purpose of this study. Therefore, the purpose of this study aims to dismantle the myth of local development in order to broadly grasp the description of societal factors as life survival strategy of experienced doubled marginalization. The doubled marginalization experienced by the Bajo community especially in the Hakatutobu village in Pomalaa Kolaka occurs on two levels. First is the 
marginalization due to the land acquisiotion for mining expansion and related activities that prevent the locals to get benefits. Second is the marginalization of socio-economic deterioration due to changing life survival strategy affected by the coastal environmental destruction. Those two determinants are important to bring about a fairly sociological analysis of the marginalization of the Bajo-community that both occur in two villages (Hakatutobu and Tambea). This because so far such study is still lacking, instead the study about the Pomalaa region mosty seen or presented through positivistic approaches. As a consequence, such positivistic studies only reveal superfacial problems but tend to ignore the roots of the marginalization itself.

To figure out a better sociological analysis on the marginalization of the Bajo Community due to mining expansion in Pomalaa Kolaka, Southeast Sulawesi, it is necessary to understand the results of previous studies related to the aims of this research. The most recent research related to the marginalization of the local community carried out by Nyoman Suryaman (2015), concludes that the empowerment for fishery activities and the communities can be a solution for providing life survival and or economic resilience for the locals especially those affected by local development. Azhar's (2013) states that the marginalization of Unggaran citizens occured due to limited access for ownership of their land rights statuses due to ambilance and or overlapping governmental related policies on the land use. The study reveals the role of investment from the non-locals as the main cause of the problem of marginalization. It is because such investment of the land use has become a vital medium to boost locally tourism industry especially addressed for the domestic tourists with an expectation that will also increase entrepreunership skills for the locals. The concept of marginalization has related aspects to the fields of sociology, economics and politics. According to Aditya Anupkumar (2009: 3), marginalization is about the condition of particular society being helpless due to deviation of disfunctional socio-economic and political system for the society existence, and or experiencing social dysfunction. Therefore active communities are needed so that they are able to empower themselves optimally. According to Amitai Etzioni (in Poloma, 2010) active communities are people who control their social world, which is not controlled by outside forces or other active forces. A society is said to be active agents when the community is able to hold knowledge as a key to social transformation, both scientific and social knowledge.

In addition to the theory of active society, Gramscian hegemony theory is also applied for this research. This theory builds on the premise of the importance of ideas and the insufficient physical strength in social and political control. In order for those who are being controlled to obey the authorities, not only must they feel that they possess and internalize the values and norms of the authorities, but more than that they also have to give their subordinate approval. This is what Gramsci meant by 
Jurnal Pemikiran Sosiologi Volume 7 No.2 2020

The Expansion of Nickel Mining, Environmentak Damage and Determinants' of the Bajo Community Marginalization in Pomalaa Regency, Southeast Sulawesi

Irawati

"hegemony" or being controlled by "moral and intellectual leadership" (Gramsci in Sugiono 2006: 31). The theory about economic development begins from the perspective of neoliberalism is an understanding that claims the important role of free markets and foreign capital for development. The assumption is that development has a positive correlation with capital. Harvey explained about the phenomenon of neoliberalism as follows:

"Neoliberalism is in the first instance a theory of political economic practices that proposes that human well-being can best be advanced by liberating individual entrepreneurial freedoms and skills within an institutional framework characterized by strong private property rights, free markets and free trade. The role of the state is to create and preserve an institutional framework appropriate to such practices. The state has to guarantee, for example, the quality and integrity of money. It must also set up those military, defence, police and legal structures and functions required to secure private property rights and to guarantee, by force if need be, the proper functioning of markets. Furthermore, if markets do not exist (in areas such as land, water, education, health care, social security, or environmental pollution) then they must be created, by state action if necessary. But beyond these tasks the state should not venture. State interventions in markets (once created) must be kept to a bare minimum because, according to the theory, the state cannot possibly possess enough information to second-guess market signals (prices) and because powerful interest groups will inevitably distort and bias state interventions (particularly in democracies) for their own benefit"

(Harvey 2005:2).

Thus, globalization, which is marked by advances in information technology, creates a free and broad world order without space barriers. Capitalism is experiencing an expansion of development which is ultimately global (Emanuel Wallerstein, 1990). Thus, the future of the world economy is in the grip of capitalism (Berger, 1990). Unfortunately, he only paid little attention to the internal contradictions and cruelty of the system. (Lippit, 2005). Habermas (1984) mentions that capitalism will cause ecological imbalances, anthropological imbalances (disruption of personal systems), and international imbalances. Therefore, Gwynne \& Kay, (2004) offers an alternative for the form of neostructuralism. Other thoughts such as White in the book "Constructing A Democratic Developmental State" in The Democratic Developmental State: Politics and Institutional Design provide an alternative to the failure of capitalism in the form of an idea of building a democratic state. (White 1998: 17-51). 


\section{Research Findings: Environmental Damage,}

Ecological Impacts and the Marginalization of the

\section{Bajo Community.}

Observation or fieldwork study of this research was conducted from November 1st, 2017 until March 31st, 2018. The fieldwork findings show that socio-economic aspects have contributed to constanly marginalization among the Bajo community. The description taken from the fieldwork findings will be discussed here. When I first visited the Tambea village and Hakatetobu village, in Pomalaa Subdistrict, Kolaka Regency, I found the reality of a naked natural destruction in the region and thus I have the feeling of desperation for witnessing the precarious socio-economic conditions of the villagers due to marginalization.

The initial exploration on tracing other determinants of the Bajo communitys' marginalization is also conducted by researching related documents, e.g.; reports of government activities, NGOs, companies, universities and other expert research on the field. Data obtained from the fieldwork shows that ecological damage (environmental destruction) is only reported as a minor cause that accelerates the marginalization of the Bajo community.

The Tambea village and the Hakatetobu village, in Pomalaa sub District, Kolaka Regency are two villages for the settlements of the adat community (customary-aboriginal tribe) known as the Bajo community. During my fieldwork study for five months in these two villages, I have witnessed a marginalization that occured among the Bajo tribe community. During an intensive five months residency fieldwork in both villages, I witness myself that the Bajo community in these two villages is really depending on the existence of water (aquatic) life.

My first question during the fieldwork was about questioning on how these two villages actually not to be identified as the preservation areas by the state (or in Indonesia should be categorized as 'daerah pedalaman' or remote category that deserve protection from the central government). Maybe because the villages are very easily accessible for transportation from the capital city of Kolaka district, as well as from Kendari, or the capital of Southeast Sulawesi Province. Both of these villages are located on the Kendari-Kolaka axis road. As the villages are the basis settlement location for the Bajo tribes, these two villages display unique cultural significance whereas the tribes relying their lives on aquatic culture (aquafarming). Most of the residents in both villages live on the sea waters and of course inhabit the coastal areas. After five months of intensive observation, living among the Bajo community in both two villages I have collected two important findings that I would like to describe in relation to the precarious socio-economic conditions of the Bajo community. First is the high rates of poverty among the tribe. Second is the socio-economic gap between the richests and the poorers. Such socio-economic gap also occurs among the people of the Bajo tribe, also between the Bajo and non-Bajo tribal communities. 
The Bajo people are predominantly having low-income and livingin the very poor circumstances. Meanwhile, the non-Bajo communities are predominantly becoming middle to upper class groups with higher income. The economic disparity between the Bajo and non-Bajo communities in the area has been increasingly widened due to the expansion of the nickel mining activities in the region of Pomalaa operated by the corporation like PT. Antam, Tbk. The environmental deterioration is thus aggravated by the fact that the nickel mining company seems to neglect the importance of aquatic life culture for the inhabittans of the affected areas. Aquatic life here is defined as means of living in relation to the existence of water and or sea lives, including living near water or cultivating means of life supports from or in water.

Although some members of the Bajo tribe also become land farmers, the company denies the preservation of the nearby forest. The location of these villages are actually in the middle of the mining sites exploration for processing nickel, that are owned not only by PT. Antam, but also with other subcontractor companies. For me, living in the location is not only witnessing the precarious socio-economic conditions. Moreover, it seems to be very much depressing as well for the locals to think about their future and or cultural existence. Living with an uncertain incomes, while the necessities of life continue to increase. For some members of the Bajo tribe, further cultural destruction of their existence also occurs as a result of the environmental damages in the Tambe village and especially in the Hokatotebu village but no authority pays serious attention on the issues .

The following samples from the interviews that I conducted during the fieldwork confirm the above description on the socio-economic precarious conditions for the Bajo tribe:

... "our fishermen's catches were far better in the past than today..for example we used to have 1 ton fishes every time we went sailing, however, now we've got only $100 \mathrm{~kg}$ ! We do more efforts and hardship follows, but then the price of the fish always goes lower and cheaper than before.moreover the price for sailing is getting more higher (the cost for fishery is more expensive)..."

(Interview transcript with $\mathrm{Mr}$ Abadi, conducted on 25th November 2017).

In line with Mr. Abadi's statement, the following statement from Mr. Alhamid also adds that:

... "In the past, seaweed cultivation was very good, but after the environmental damage, we cannot go any further, now we have to go far more out to cultivate seaweed, but the contaminated water always haunts..."

(Interview transcript with Mr. Alhamid on November 25th, 2017).

Meanwhile, another informant also confirms the descriptions of doubled marginalization due to the environmental destruction. This is for example stated by Mr. Ruslan Gafur; 
Jurnal Pemikiran Sosiologi Volume 7 No.2 2020

The Expansion of Nickel Mining, Environmentak Damage and Determinants' of the Bajo Community Marginalization in Pomalaa Regency, Southeast Sulawesi

Irawati

... "historically there were only 7 households in Tambea who moved to Hakatutobu village, that used to be a wild forest in the past, no one lives there before..the reason for our tribe moving from Tambea to Hakatotubu was because there was no garden in Tambea, our lives were solely depended on the sea, while in Hakatutobu we can cultivate plants or making our garden, so if we could not sail, the land farming would be another alternative means of our living.. The initial plan of the government (in the new order era), Hakatutobu Village was specifically designed for accomodating the Bajo tribe population, but over time, our offsprings have their mixmarriage families with other tribes so now it is mixed. There are more members of the outsider tribes here than the Bajo tribe. Fishermen are burdened with the price of fuels which is quite expensive, especially if they have to go far more out to be able to catch fish, or cultivate seaweed. The price of fish is determined by Pappalele- the wholesalers, when we have lots of fish the price will go down, when there are lesser fish, the prices will go up, it happens all the time and no authority pay attention on such injustice. Fishermen do not have the ability to determine the price of fish, fishermen are forced to sell their fish to Pappalele because they already owed him (for the down payment of the sailing costs)."

(Interview transcript with Mr. Ruslan Gafur on November 25th, 2017).
The precarious economic condition of the Bajo tribe also revealed by Mr. Sardi, whom I managed to interview in depth. He said that:

... "Bajo people live on boats, so all of the land that distributed in the past has already been sold. All the people here only make their living on exploration (traditional mining of the nickel prior to the existence of the corporation activities) in the mountain including cultivating plants or fruits, in other seasons we always spent on the sea, nothing else. But now nothing that we can benefit anymore from the mountain because it has been taken out and expanded by the mining company, while on the sea we have to struggle more with hardship due to collateral damage on the coastal areas as well as polluted (contaminated) water! So you have to go far more out to the sea to be able to catch the fishes or cultivate seaweed. In the past, we did not have to worry about preserving the fishes (producing dried salted fishes) near our homes on the shore..just like our children were happy to play around on the shore like playing football because the sand beaches were clean, without worrying to get sick..but today, those seem to be almost impossible for us...we have no more beautiful dream for the future..."

(Interview transcript with Mr. Sardi on November 27th, 2017).

Another key informant of this study also provides an information on the socio-economic precarious condition of the Bajo community. This is exemplified by Mr. H. Mursalim, the secretary of Hakatotebu Village, he said that: 
Jurnal Pemikiran Sosiologi Volume 7 No.2 2020

The Expansion of Nickel Mining, Environmentak Damage and Determinants' of the Bajo Community Marginalization in Pomalaa Regency, Southeast Sulawesi

Irawati

... "Seaweed used to be very good here, very fast growing, sea cucumber cultivation, faucets, etc., but now there is nothing more. Fishing must also be reaching far more out, because the closer sea here is already contaminated and the quality of aquatic life is at danger for our health."

(Interview transcript with Mr. H. Mursalim, on 27th November 2017).

Those above descriptive data taken from the fieldstudy underline the reality of actual marginalization among the Bajo community in Tambea village and Hakatutobu village, Pomalaa sub District, Kolaka Regency due to environmental destruction that has been resulted not only in socio economic disparities, but also almost a cultural genocide against the ancestral heritage of the Bajo people, namely cultivating the aquatic culture like fisheries and or boat-sailing activities. For the Bajo community, their lives are almost entirely relying on water. The coastal area where they have been inhabitted for ages is the place for resting and learning. For the Bajo, their existence come from the water, they are born on the sea, the place where they grow, eat, sleep, and thus socialize with people (human beings) and the nature. Because they believe that they are born and grow up on the sea, therefore water or aquatic life is a primary life existence for the tribe. While their source of life is the sea, at sea they find food, at sea they look for living expenses, at sea they look for clothes, at sea they look for school fees for their children, and they consider the sea to be their future savior for their children.
For the Bajo tribe, living at sea is their utmost need that they found impossible to be separated from their daily lives. On the other hand, the dependence of the Bajo on the sea seems to make the tribe vulnerable especially due to the expansive environmental damage affected by the contamination of the areas from residues of the nickel mining activities that further affected some degrees of degradation of the aquatic environment where they live. The environmental damage that occurs especially in the village of Hakatutobu (that is surrounded by mountainous area) can be seen from the sedimentation caused by soil erosion, This is because the village is location closer from the nickel ore mining location. Meanwhile, the environmental damage in the Tambea village (that is located by the shore - closer to the coastal area at sea) can be seen from the contaminated water because the activities taken place at the nearby loading-unloading port from where the mining company transport the nickel to other places in Indonesia. At the local loading-unloading port known as "Jeti" - nowadays besides PT Antam, there are other sub-contractor local companies operate on the field for supporting the expansion of the nickel mining industry. The environmental destruction only has been resulted in the poor quality of sea water, but also has been affected in the loss of aquamarine life such as sea cucumbers, taps, baronang fish, seaweed etc. Today, beside PT Antam, some other nickel mining companies are still operating in the field, namely; PT. Tosida, PT. Asia Mineral Mining (AMM), PT. Putra Mekongga Sejahtera (PMS), and PT. Ivory Coconut. 
In addition to the environmental damage in Pomalaa region due to the mining activities, another version of historical dispute about the existence of the village of Hokatutobu as an extended new village for the Bajo community after the Tambe village is testified by Mr. H. Burman who is also considered as the respected man among the Bajo tribe. He briefly said that:

... "PT. Antam was ahead of us in this Hokatutobu village, it may even be said that this village was an area of Antam's gift to the community as the form of economic empowerment for us in the new order era.. But in 2007 - 2008 new companies have also emerged and operate as well to extract the nickel mines. Those expansion and multiple companies' activities that have been now resulted in the collateral damages for our environment. So it is naive to say that only PT Antam that solely caused the problem. I think PT. Antam has tried hard to cope with preventing more environmental damage to the coastal areas, but miners from other companies do not care, so maybe I think PT. Antam also cannot help much"

(Interview transcript with Mr. H. Burman, conducted on 27th November 2017).

The testimonies from the informants of the Bajo tribe members show that the problem is a way more complicated. It also means that in the region environmental damage is an undeniable fact, but concerns over resolving the environmental destruction is also becoming a disputable issue. In the case of the natural resources exploitation in Pomalaa, Kolaka Regency, there are four involvements of the capitals that have been operating in the nickel mining industry which neglecting its impacts on ecological system. In other words, it is visible for us to see that global capitalism also operates on the mining sites. The global capitalism in this sense operates through investments within the mining corporations and their locally subcontractors whose background mostly controlled by the local elites.

The absence of land ownership certification makes some residents decide to accept the form of company and government offer which is mediated by the local local elite on behalf of the Bajo community. Generally, local people only own land (without certificates) and housing (made of wood and thatch), which De Soto often refers to as dead capital. As a result, their livelihoods tend to be engaged in agriculture and marine affairs, the results of which can only be enjoyed for daily life.

\section{Socio-Cultural Determinants' of the Bajo Community Marginalization}

Besides socio-economic determinants' of the Bajo community marginalization due to the environmental destruction, I think there are other socio-cultural determinats that have also contributed to weaken the Bajo community existence of aquatic life survival especially in accessing the circle of the elite for addressing significant policy for environmental treatment and other socio-economic 
supports for the Bajo community. It is also a proof that the education levels of the Bajo tribe is considered relatively low. In average, the people only accomplished primary and secondary education. In the Hakatutobu village, there are only three people who earned bachelor degree (attended college or university).

From my observation on the fieldwork study, it was very obvious that among the Bajo community a concern on leadership also prevails. This is because there is a growing envious insecurity when the Bajo community witness other communities of having better economic access and or entry to the decision making position for resolving the environmental damage. This is exemplified by my interview with one younger member of the Bajo community, Mr. Daning as follows;

"Frankly spoken, in my view, PT. Antam is quite responsive when we (the Bajo community) need help for instance like when we have to deal with land errosion. However, the efforts to negotiate with the authority are hampered by the management and other intermediary actors who claim on behalf of the corporation and or the government. I have to say that we are quite jealous when seeing many other Tambea people employed PT. Antam, and only one person from our tribe who comes from Hakatutobu village employed by the company," and they said it is because we have lacking qualification for working within the company due to our lower levels of the education"
(Interview transcript with Mr. Daning on 27th November 2017) .

Among the older tribe members of the Bajo community there is also a growing fear of preserving their ancestral herritage of maintaining aquatic life culture especially due to the fact that the younger generation of the Bajo community itself seem to no longer tightly uphold the cultural belief, unlike the older generation. Some of the older tribe members accused the mix-marriages (inter-ethnic marriages) with other so-called non-Bajo communities as the reason of the fading cultural belief in maintaining aquatic life culture. Such fear, however, cannot be put aside, because the Bajo ancestral herritage on the aquatic culture brings about the values of local wisdom in treating and preserving the sea and its ecosystem in its natural ballance.

According to the narratives taken from the fieldwork study, the material transformation of the coastal areas is also induced by urbanization that consequently has been affected in the daily habits of the locals to live their lives like the urban people. This is for example shown by a growing consumptive behaviors among the residents in the Pomalaa regions. People are becoming more individual and thus have no interest in upholding traditional belief and practices including embracing aquatic life culture that is considered obsolescent (especially among the younger generation of the Bajo community).

Nevertheless, resistance to maintain the cultural value and the local wisdom practice among 
the Bajo community still remains. This is because, some younger people of the Bajo community realize some good teachings of their ancestral belief that are still socialized in everyday interactions with their older generation, for instance the act of not being too greedy, and the act for saving resources and not to waste food easily.

\section{E. Conclusion}

The findings of this research shows that liberal economy can be run without government intervention at large. The assumption of such laissez faire is believed to increase prosperity. In fact, such assumption is untrue. What happens actually is the large profits from the natural resources exploitation become the largest portions of benefits for the corporation shared with the elites. On the other hand, marginalization of the local communities - especially those who considered unfit to meet the modes of natural exploitation like the Bajo community continues.

The easy prosedures of the nickel mining operation uphold by the enabling institutions has made capitalism continue to ensnare Indonesia, especially the customary communities who experience socio-economic and cultural insjustices. Lippit (2005) argues that in Indonesia, for example, companies that cannot afford to pay their debts can continue to operate with few obstacles for many years.
To sum up this study, there are three major determinants of the Bajo community's marginalization. First, contaminated water due to coastal pollution. Second, unavailable alternative livelihood supports due to limited access for economic benefits from the mining expansion. Third, lacking bargaining ability of the Bajo community in dealing with the politics of the environmental destruction due to limited access for entering the structure of policymakers preserved by the local cultural norms.

The results of this study also shows that despite the fact of experiencing weakened socioeconomic and cultural determinants for a better quality of life, the Bajo community remains struggling to cope with the impacts of global capitalism that has been resulted in the natural resources exploitation that endanger their survival strategies. In this sense, although the community seem to have more difficulties in maintaining their aquatic life culture, the Bajo community in Pomalaa region is considered not totaly passive in facing the problem of environmental destruction. They are still considered as active agents that remain resisting against the dominant and hegemonic economic agencies that operate in the Pomalaa region. 


\section{Reference}

Anshari Gusti Z. dkk. 2005. “Marjinalisasi Masyarakat Miskin di Sekitar Hutan: Studi Kasus HPHH 100 Ha di Kabupaten Sintang, Provinsi Kalimantan Barat.” Decentralisation Brief No. 9

(http://www.cifor.org/publications/pdf_files /descbrief/DescBrief9.pdf).

Azhar, Ali Muhammad. 2013. “Marjinalisasi Masyarakat di Daerah Pariwisata (Studi Kasus di Desa Ungasan, Kecamatan Kuta Selatan, Kabupaten Badung)." Administratio: Jurnal Ilmiah Administrasi Publik dan Pembangunan ,Vol. 4 (2) (tanpa halaman)

Beck, Urich, 2000, What Is Globalization? Cambridge: Polity Press.

Berger, Peter, 1990. Revolusi Kapitalis (transl), Jakarta: LP3ES,

Boli, J., and Lechner F.J. 2009, "Theory of Globalization," in Bryan S. Tuner (ed). The New Blackwell Companion to Social Theory. Molden: Blackwell Publishing Ltd.

De Soto, Hernando. 2006. The Mystery of Capital: Rahasia Kejayaan Kapitalisme Barat. Jakarta: Qalam.

Denzin, N.K. \& Y.S. Lincoln. 2000. Handbook of Qualitative Research. London: Sage, Thousand Oaks.
Esterberg. K. G. 2002. Qualitative Methods in Social Research (15th Ed.). Boston: McGraw-Hil

Fakih, Mansour. 2009. Runtuhnya Teori Pembangunan dan Globalisasi. Yogyakarta: INSIST Press.

Geerts, Cliford. 1973. Thick Description: Towards an Interpretive Theory of Culture, the Interpretive of Culture. New York: Fordhan University Press.

Gwynne \& Kay. 2004. Latin America Transformed: Globalization and Modernity. London: Routledge.

Habermas, Juergen. 1984. The Philosophical Discourse of Modernity. Cambridge: Polity Press.

Harvey, David. 2006. A Brief History of Neoliberalism. Oxford: Oxford University Press.

Heilbroner, R.L. 1991. Hakikat dan Logika Kapitalisme (transl). Jakarta: LP3ES.

Hayek, F.A., 1978, “The Principles of A Liberal Social Order", in Anthony de Crespigny and Jeremy Cronin (eds), Ideologies of Politics. Oxford: Oxford University Press.

Kellner, Douglas, 2002, "Theorizing Globalization", Sociological Theory.20 (3): 285-305.

Lippit, Victor D, 2005, Capitalism (Routledge Frontiers of Political Economy). London: Routledge. 
Maximus, Regus. 2011. “Tambang dan Perlawanan Rakyat: Studi Kasus Tambang di Manggarai NTT." Masyarakat: Jurnal Sosiologi Vol. 16 (1): $1-26$.

Moleong, J. Lexy. 1991. Metode Riset Kualitatif. Bandung: Rosdakarya.

Obie, Muhammad 2015. "Perampasan Hak Ulayat Pesisir dan Laut Komunitas Suku Bajo (Studi Kasus Pengelolaan Sumberdaya Pesisir dan Laut Teluk Tomini)” Thesis. Bogor: Institut Pertanian Bogor.

Patria, Nesar \& Andi Arief. 2003. Antoni Gramsci Negara \& Hegemony. Yogyakarta: Pustaka Students

Ritzer, George and Douglas J. Goodman, 2004. Sociological Theory. New York: McGraw-Hill.

Ritzer, 2007, The Globalization of Nothing (2nd Edition). CA:, Thousand Oaks and Pine Forge Press.

Robertson, R., 1992. Globalization. London and Newsbury Park, CA: Sage.

Rand, A. 1970, Capitalism: The Ideal Unknown. New York: A Signet Book.

Saad, Sudirman. 2009. Bajo Berumah di Laut. Jakarta: Coremap

Sugiono, Muhadi 2006. Kritik Antonio Gramsci Terhadap Pembangunan Dunia Ketiga. Yogyakarta: Pustaka Pelajar.
Surya Batara 2011. “Perubahan Fisik Spatial Kawasan Pinggiran Memarjinalisasikan Komunitas Lokal (Kasus Kota Baru Metro Tanjung Bunga, Makasar)." Jurnal Tataloka Vol. 13 (4): 212223.

Suryawan, Nyoman 2015. "Alih Fungsi Pesisir Pascareklamasi dan Implikasinya terhadap Marjinalisasi Nelayan di Pulau Serangan, Denpasar." Jurnal Kajian Bali Vol. 5 (1): 57-80.

Strauss, Anslem, Corbin, Juliet. 2003. Dasar-Dasar Penelitian Kualitatif: Tata Langkah dan Teknik-Teknik Teoritisasi Data (terj). Yogyakarta: Pustaka Pelajar.

Tahara Tasrifin. 2014. “Kebangkitan Identitas Orang Bajo di Kepulauan Wakatobi." Jurnal Antropologi Indonesia Vol. 34 (1).

Tony Killick, 1998, Aid and the Political Economy of Policy Change. London and New York: Routledge.

Wallerstein, I. 1990. "Culture as the Ideological Battleground of the Modern World-System" Theory, Culture Society .7: 31-25.

Wallerstein, I. 2003. The Decline of American Power. New York: New Press.

Wallerstein, I. 2004. World-System Analysis: An Introduction. Durham, NC: Duke University Press.

Wibowo Hendro, Bahri, \& Harto. 2016."Optimalisasi Peran Masyarakat Nelayan Batam dalam 
Jurnal Pemikiran Sosiologi Volume 7 No.2 2020

The Expansion of Nickel Mining, Environmentak Damage and Determinants' of the Bajo Community Marginalization in Pomalaa Regency, Southeast Sulawesi

Irawati

Pengembangan Ekonomi." SOSIO-DIDAKTIKA

Vol. 3 (1): 92-104.

White, G., 1998, “Constructing A Democratic Developmental State," in Mark Robinson and Gordon White (eds). The Democratic Developmental State: Politics and Institutional Design. Oxford: Oxford University Press.

Yuwana, Nurhadi, Nugroho, \& Abdullah. 2012. "Kontestasi Elit dan Marjinalisasi Penduduk Lokal di Lokasi Pertambangan Batubara Kutai Kartanegara." Jurnal Pemikiran Sosiologi Vol 1 (2): $1-20$

Zacot, F. Robert. 2008. Orang Bajo: Suku Pengembara Laut (Pengalaman Seorang Antropolog) (trans). Jakarta: KPG (Kepustakaan Populer Gramedia). 